Article

\title{
Spore Viability and Cell Wall Integrity of Cordyceps pruinosa Treated with an Electric Shock-Free, Atmospheric-Pressure Air Plasma Jet
}

\author{
Hyeongjin Noh ${ }^{1}{ }^{\mathbb{D}}$, Ji Eun Kim ${ }^{1}$, Jun Young Kim ${ }^{1}$, Seong Hwan Kim ${ }^{1, *}$, Ihn Han ${ }^{2}$, \\ Jun Sup Lim ${ }^{2}$, Se Hoon $\mathrm{Ki}^{2}\left(\mathbb{D}\right.$, Eun Ha Choi ${ }^{2}$ and Geon Joon Lee ${ }^{2, *}$ \\ 1 Department of Microbiology and Institute of Biodiversity, Dankook University, Cheonan 31116, Korea \\ 2 Department of Electrical and Biological Physics/Plasma Bioscience Research Center, Kwangwoon University, \\ Seoul 01897, Korea \\ * Correspondence: piceae@dankook.ac.kr (S.H.K.); gjlee@kw.ac.kr (G.J.L.); \\ Tel.: +82-41-550-3454 (S.H.K.); +82-2-940-8619 (G.J.L.)
}

Received: 26 August 2019; Accepted: 12 September 2019; Published: 18 September 2019

check for updates

\begin{abstract}
Atmospheric-pressure Ar plasma jets are known to be detrimental to Cordyceps pruinosa spores. However, it is not clear what kinds of reactive species are more effective with regard to fungal cell death. Herein, we study which reactive species plays pivotal roles in the death of fungal spores using an electric shock-free, atmospheric-pressure air plasma jet, simply called soft plasma jet. Plasma treatment significantly reduced the spore viability and damaged fungal DNA. As observed from the circular dichroism spectra, scanning electron microscope images, and flow cytometric measurements, cell wall integrity was decreased by reactive oxygen and nitrogen species (RONS) from the plasma itself and the plasma-activated water. Consequently, degradation of the spore cell wall allows RONS from the plasma to reach the intracellular components. Such plasma-induced intracellular RONS can attack spore DNA and other intracellular components, as confirmed by electrophoresis analysis and phosphorylated histone measurement. In addition, weakening of the spore cell wall allowed for the loss of intracellular components, which can lead to cell death. Plasma radicals were investigated by measuring the optical emission spectrum of the soft plasma jet, and intracellular reactive oxygen species were confirmed by measuring the fluorescence of $2^{\prime}, 7^{\prime}$-dichlorodihydrofluorescein-diacetate ( $\mathrm{H}_{2} \mathrm{DCF}-\mathrm{DA}$ )-stained spores. The soft plasma jet generated considerable amounts of $\mathrm{H}_{2} \mathrm{O}_{2}$ and $\mathrm{NO}_{x}$ but a very small number of $O H$ radicals as compared to the atmospheric-pressure $A r$ plasma jet; this indicates that plasma-induced long-lived reactive species $\left(\mathrm{H}_{2} \mathrm{O}_{2}\right.$ and $\left.\mathrm{NO}_{x}\right)$ play an important role in the weakening of spore cell walls and cell death.
\end{abstract}

Keywords: electric shock-free plasma; reactive oxygen and nitrogen species; cell wall integrity; DNA; phosphorylated histone; flow cytometry; SEM; circular dichroism

\section{Introduction}

Entomopathogenic fungi in the form of microscopic spores adhere to the outer surfaces of insect bodies. When the spores germinate, they penetrate the host body and proliferate in the body cavity, ultimately killing the host [1]. The fungi are recognized as environmentally safe natural-mortality agents for the biological control of insects and other arthropod pests [2]. They are also considered rich sources of structurally novel biologically active substances [3]. The common and important entomopathogenic fungus is the teleomorphic phase of the genus Cordyceps, which includes anamorphic phase names of Beauveria, Isaria, Hirsutella, Metarhizium, and Nomuraea. To apply these insect-killing fungi to biological control and other biotechnology areas, an understanding of their ability to tolerate diverse environmental stresses is required. 
The effects of ionizing radiation, plasma, ultraviolet (UV) light, and heat-treatment stresses on fungal cell inactivation have been previously studied. Nonthermal-atmospheric-pressure plasma jets (APPJs) and dielectric-barrier-discharge plasma have been used for various plasma treatments, such as cancer treatment, wound healing, sterilization and inactivation of biological materials [4-11]. However, the effects of plasma treatment on eukaryotic microbiological materials, such as entomopathogenic fungal cells, have not been studied thoroughly. There have been only two reports in which oxidative stresses generated by an APPJ device were applied to Cordyceps bassiana and C. pruinosa spores [12,13]. In these previous studies, both plasma radicals and an electric field were applied to the fungal sample by positioning it between a needle-shaped powered electrode and a surface electrode attached to the bottom of a microwell plate. If the plasma radicals are generated through discharge between the coaxial electrodes, the radicals can be applied to the fungal samples without an electric shock. But, it has not been thoroughly investigated how the fungal cells can be stressed by plasma radicals in the absence of electric shocks. Reactive oxygen and nitrogen species (RONS) from the plasma itself and plasma-activated water depend on parameters such as the plasma devices, plasma working gases, and background medium. Therefore, the types and amounts of plasma-generated RONS can be determined by selecting an appropriate plasma working gas. The atmospheric-pressure air plasma jet generates unique RONS different from those of the atmospheric-pressure Ar plasma jet. If an electric shock-free, atmospheric-pressure air plasma jet is used to treat C. pruinosa spores in an aqueous solution, the cellular response of the air plasma-treated fungal spores will be different to that of Ar plasma-treated fungal spores due to the difference in plasma-induced RONS.

This study was undertaken to elucidate the death mechanism of fungal spores using an electric shock-free, atmospheric-pressure air plasma jet, simply called soft plasma jet. For this aim, we measured the viability of the plasma-treated spores and investigated how the degree of DNA damage and cell wall rigidity affect the viability of plasma-treated C. pruinosa spores. Viability of the plasma-treated spores was investigated by counting the number of living and dead spores. Plasma-generated reactive species were examined by optical emission spectra, and intracellular ROS was confirmed by measuring the fluorescence of $\mathrm{H}_{2} D C F-D A$-stained $C$. pruinosa spores. Cell shapes and wall surfaces of plasma-treated spores were imaged using a scanning electron microscope (SEM), and the loss of cell wall integrity was measured using the fluorescence intensity of propidium iodide (PI)-stained spores. The effect of plasma treatment on C. pruinosa DNA was determined by measuring phosphorylation of the histone protein from double-strand breaks. Plasma-induced changes in the spore viability and degree of DNA damage were discussed by considering variations in the cell wall structure of the plasma-treated fungal spores.

\section{Materials and Experimental Methods}

\subsection{Fungal Strains and Spore Preparation}

Cordyceps pruinosa was used for this study. To grow a solid C. pruinosa culture, the fungus was cultured in Sabouraud dextrose agar with yeast extract (SDAY) media for 7 days in the dark at $25^{\circ} \mathrm{C}$. Fungal spores formed on the solid media and were flooded with sterile water, resuspended by shaking, and filtered through several layers of sterile gauze. The prepared spore solution was cultured in $100 \mathrm{~mL}$ Sabouraud dextrose yeast (SDY) broth of $300 \mathrm{~mL}$ glass flask at $25^{\circ} \mathrm{C}$ for 5 days while shaken at $200 \mathrm{rpm}$. Spores from the liquid culture were filtered again through two layers of sterile gauze, washed twice using sterile water through a bench-top centrifuge at $7000 \mathrm{rpm}$ for $10 \mathrm{~min}$ (Thermo Fisher Scientific, Sorvall ${ }^{\mathrm{TM}}$ ST 16, Waltham, MA, USA), concentrated to $5 \times 10^{7}$ spores $/ \mathrm{mL}$ and then used for the plasma-induced RONS treatment. The spores were counted using a hemocytometer (Sigma-Aldrich, Bright-Line ${ }^{\mathrm{TM}}$, St. Louis, MO, USA). 
(a)
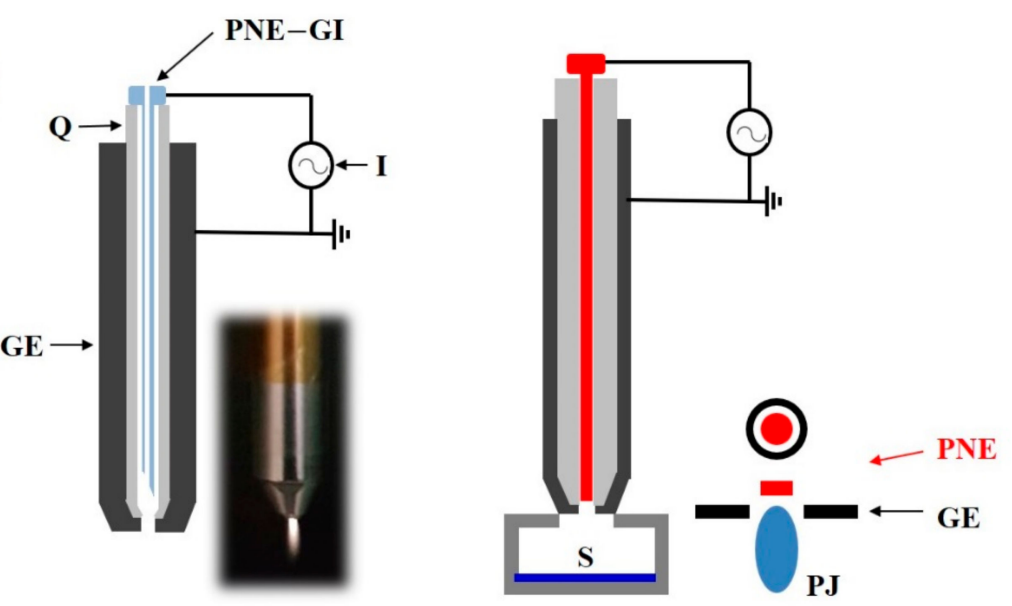

(b)
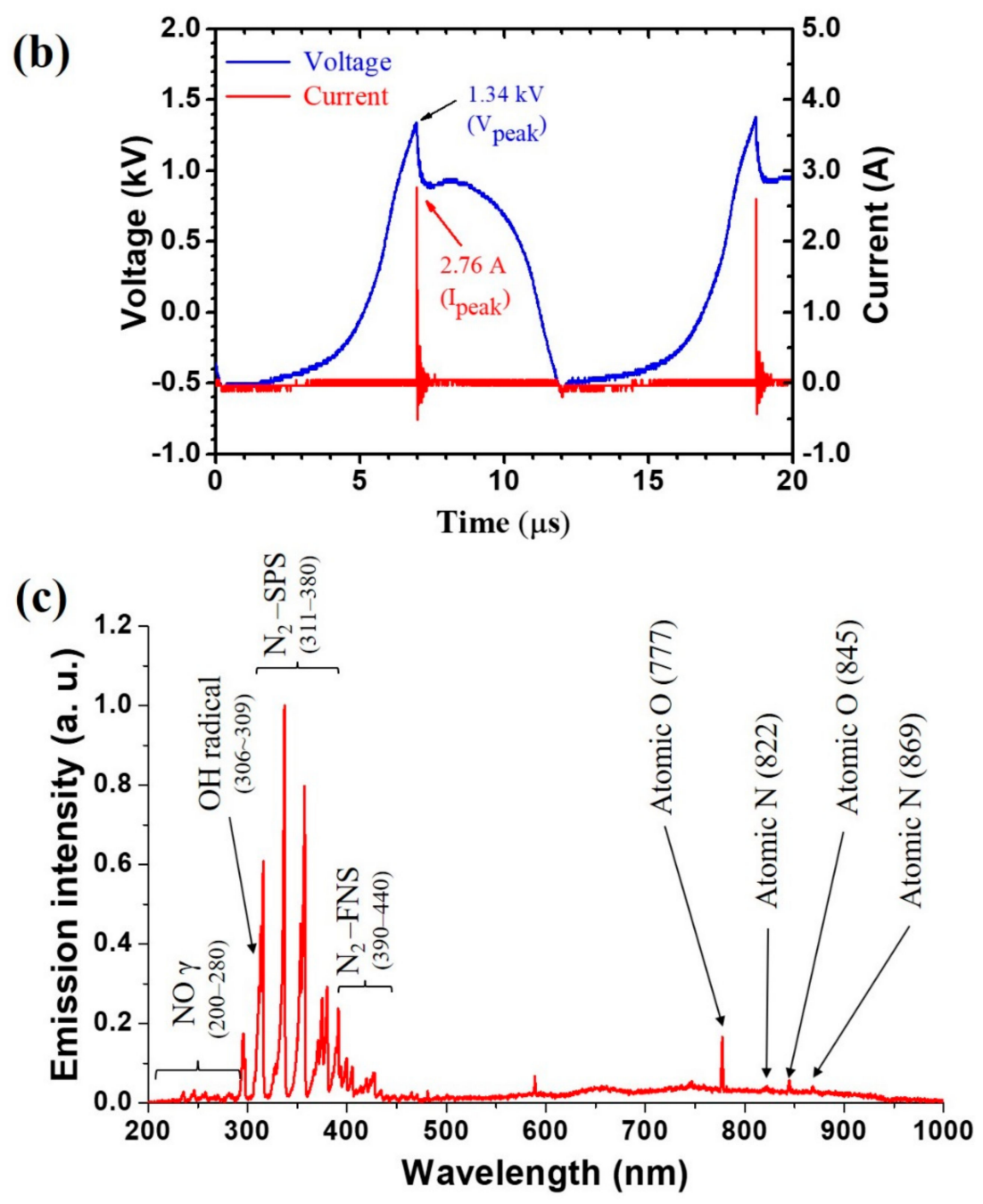

Figure 1. (a) Experimental layout, photo and schematic diagram of an electric shock-free, atmospheric-pressure air plasma jet, I, Inverter, PNE-GI, Powered needle electrode and Gas input, Q, Cylindrical quartz tube, GE, Grounded electrode, S, Sample, PJ, Plasma jet, (b) typical voltage and current profiles of the plasma discharge, and (c) optical emission spectrum of the soft plasma jet.

2.2. Soft Plasma Jet Device, Plasma-Activated Water, Plasma Treatments, and Spore Viability

Figure 1a illustrates an experimental layout of the electric shock-free plasma jet, which consists mainly of a power supply, needle electrode, cylindrical quartz tube, and cylindrical tube electrode. 
The quartz tube served as a dielectric barrier between the electrodes to induce an electrical discharge. Plasma radicals were generated by electrodes separated by a dielectric barrier. The outer diameters of the powered needle electrode, cylindrical quartz tube, and cylindrical copper tube were $2.0 \mathrm{~mm}, 10.0$ $\mathrm{mm}$, and $12.0 \mathrm{~mm}$, respectively. A plasma jet threw out through a $1 \mathrm{~mm}$ hole to the open air at a flow rate of $1.5 \mathrm{~L} / \mathrm{min}$. The plasma plume length was approximately $5 \mathrm{~mm}$. The needle-to-water surface distance was fixed at $10 \mathrm{~mm}$. A tip-to-sample distance was chosen to avoid thermal effects in the plasma-treated sample. In this research, air was used as the plasma working gas for the soft plasma jet. Electric power for the plasma device was supplied by an inverter that converts DC input to $67 \mathrm{kHz} \mathrm{AC}$ output. The optical emission spectrum of the plasma jet was measured using a UV-visible spectrometer (Ocean Optics, HR4000, USA). The concentrations of $\mathrm{H}_{2} \mathrm{O}_{2}$ and $\mathrm{NO}_{x}$ in the plasma-activated water were measured using QuantiChrom ${ }^{\mathrm{TM}}$ Peroxide Assay Kit (DIOX-250) and QuantiChrom ${ }^{\mathrm{TM}}$ Nitric Oxide Assay Kit (DIOX-100), respectively. The concentration of $\mathrm{OH}$ radical in plasma-activated water was measured using hydroxyl radical-sensitive fluorescence probe, terephthalic acid (TA). As TA molecules bind with hydroxyl radicals, their oxidation product (2-hydroxyterephthalic acid, HTA) becomes fluorescent, allowing hydroxyl radicals to be detected [14]. By comparing the fluorescence spectra of the plasma-treated TA- water solution with that of the plasma-untreated HTA- water solution, we can obtain the concentration of $\mathrm{OH}$ radical in the plasma-activated water.

To study the effects of soft plasma jet treatment, the spores were suspended in sterile water at a concentration of $5 \times 10^{7}$ spores $/ \mathrm{mL}$. Each well of six-well culture plates (SPL Life Science Co., Pocheon-si, Gyeonggi-do, Korea) received $3 \mathrm{~mL}$ of spore suspension. The spore samples were treated by the soft plasma jet. For effective plasma treatment, each well plate was covered by a polystyrene plate with a circular hole of $4 \mathrm{~mm}$ diameter, and plasma-induced radicals were delivered to a biological solution through the circular hole of the top plate. To test spore viability, spores with and without soft plasma jet treatment were diluted with sterile water up to 10-fold, spread on SDAY media, and kept at $25^{\circ} \mathrm{C}$ and incubated for 7 days which was enough time to observe visible mycelia fungal colony from survived spores.

\subsection{Spore Morphology and Cell Wall Integrity Measurements}

To investigate the effects of soft plasma jet treatment on cell wall integrity, plasma-treated $C$. pruinosa spores grown out on SDAY were examined for their status of living or dead cells. The number of live fungal colonies was counted, and their microstructures were observed using a field emission SEM (Hitachi, S-4300, Tokyo, Japan) according to the protocol of Yun et al. [15]. For morphological analysis, more than 200 individual spores of each treatment were observed at different magnification. Light scattering measurements can be related to the relative spore size distribution of fungal spores and cellular granularity, respectively. The plasma-treated C. pruinosa spores were stained with a membrane-impermeable fluorophore, PI, to investigate the influence of soft plasma jet treatment on cell wall integrity. At least 10,000 events were detected in each experiment. Flow cytometric data analysis of PI-stained spore fluorescence was performed with FACSuite ${ }^{\mathrm{TM}}$ software (BD FACSVerse, BD Biosciences, San Jose, CA, USA).

\subsection{Optical Absorption and Circular Dichroism Spectroscopic Analyses}

To investigate the optical and structural properties of plasma-treated spores and cellular components, we used UV-visible absorption, circular dichroism (CD), and fluorescence spectroscopic analyses. After plasma treatment, the plasma-activated water was replaced with fresh water, and then an aqueous spore solution was used in optical spectroscopic measurements. Optical absorption spectra were obtained using a UV-visible spectrophotometer (Agilent, 8453, Santa Clara, CA, USA) and CD spectra were measured using a chiral spectrophotometer (Jasco, J-815, Tokyo, Japan). 


\subsection{Flow Cytometric Measurement of the DNA Damage}

Flow cytometric assessment of $\gamma-H 2 A X$ staining of double-stranded DNA damage was performed according to standard flow cytometry protocols of R\&D systems. For flow cytometric measurements, plasma-treated and untreated C. pruinosa spores were adjusted to a concentration of $5 \times 10^{7}$ spores $/ \mathrm{mL}$ with sterile water, harvested, and fixed in cold $100 \%$ ethyl alcohol for $1 \mathrm{~h}$. The spores were treated with blocking solution (10\% goat serum) for $2 \mathrm{~h}$ and, the remained serum was washed three times with phosphate buffered saline-tween (PBS-T). After removing the blocking solution, the spore cells were stained with $\gamma-H 2 A X$ antibodies (ThermoFisher Scientific, mouse anti-phospho $\gamma$-H2AX antibody) for $18 \mathrm{~h}$ at $4{ }^{\circ} \mathrm{C}$. Horseradish peroxidase-conjugated immunoglobulin $\mathrm{G}$ antibodies (Serotec, Oxford, UK) were used as secondary antibodies. For flow cytometric measurements of DNA double-strand breaks, primary and secondary antibodies were diluted in PBS-T as a ratio of 1:100 and 1:1000, respectively. Flow cytometric data analysis of phosphorylated histone fluorescence was performed using FACSuite ${ }^{\mathrm{TM}}$ software as described in Section 2.3.

\subsection{Electrophoresis of Fungal Spore DNA}

A bead beater method was used for genomic DNA extraction from fungal spores. C. pruinosa spores were mixed with $0.1 \mathrm{~g}$ of glass beads and $400 \mu \mathrm{L}$ of breaking buffer in $2 \mathrm{~mL}$ microfuge tube (Sarstedt, Nümbrecht, Germany) and ruptured for 5 min using TissueLyser LT (Qiagen, Hilden, Germany). For the DNA extraction, the ruptured spores were subjected to phenol-chloroform extraction in $2 \mathrm{~mL}$ microfuge tube [16]. The obtained phenol-chloroform extract was separated into two layers by centrifugation at 13,200 rpm for $10 \mathrm{~min}$. The supernatant $(300 \mu \mathrm{L})$ was taken, moved to a clean $2 \mathrm{~mL}$ microfuge tube, mixed with $1 \mathrm{~mL}$ of $100 \%$ ethanol and $130 \mu \mathrm{L}$ of sodium acetate, and stored for $20 \mathrm{~min}$ at $-80^{\circ} \mathrm{C}$. The stored tube was centrifuged again as before at $4{ }^{\circ} \mathrm{C}$. After confirming the presence of DNA precipitate in the bottom of the microfuge tube, the supernatant was discarded, and the DNA precipitate was cleaned two times using $1 \mathrm{~mL}$ of $70 \%$ ethanol through centrifugation at 13,200 rpm for 5 min at $4{ }^{\circ} \mathrm{C}$. The washed DNA was dried using $37^{\circ} \mathrm{C}$ heating block until there is no alcohol smell. The dried DNA was dissolved in $20 \mu \mathrm{L}$ of elution buffer. A $2 \%$ agarose gel electrophoresis was run with the dissolved DNA. The DNA bands in the gel were stained with Ecodye (Biofact, Daejeon, Korea) and photographed with a Gel Documentation instrument (Daihan Scientific, Wonju, Korea).

\section{Results and Discussion}

\subsection{Viability of the Plasma-Treated C. pruinosa Spores}

Figure 2a shows the effect of soft plasma jet treatment on the viability of $C$. pruinosa spores at a concentration of $5 \times 10^{7}$ spores $/ \mathrm{mL}$. All plasma treatments resulted in a reduction in the viability of the C. pruinosa spores. The spores exposed to the plasma for $1 \mathrm{~min}$ were less sensitive than those exposed for $3 \mathrm{~min}$ or more. A 3 min treatment with the soft plasma jet resulted in 12\% spore viability, indicating that the soft plasma jet significantly inactivated $88 \%$ of fungal spore cells. Spores that survived could germinate and grow as mycelia. This decreasing spore viability with increasing plasma treatment time agrees with previous results regarding APPJ treatment of $C$. bassiana and C. pruinosa spores $[12,13]$. Although the viability of $C$. pruinosa spores treated by the soft plasma jet is similar to that treated by the APPJ, there are important differences between this research and the previous study [13]. First, the APPJ in the previous study [13] was applied to the fungal sample by positioning it between a needle-shaped powered electrode and a surface electrode attached to the bottom of a microwell plate. For the point-to-surface electrode configuration, both plasma radicals and an electric field were applied to the fungal sample. Meanwhile, the soft plasma jet was applied to fungal samples in the region without an electric shock from an electric field. In the soft plasma jet, plasma radicals are generated through discharge between the coaxial electrodes, and plasma radicals can then be applied to the fungal samples away from the plasma discharge region. The soft plasma jet-treated C. pruinosa spores exhibited reduced spore viability. Consequently, the viability of C. pruinosa spores 
can be controlled by a soft plasma jet that produces plasma radicals in the absence of an electric shock. Second, the soft plasma jet used air as the plasma working gas, but the APPJ [13] instead used $\mathrm{Ar}$ gas. Therefore, the atmospheric-pressure air plasma jet (i.e., the soft plasma jet) can generate unique reactive oxygen and nitrogen species different from those generated using the atmospheric-pressure $\mathrm{Ar}$ plasma jet (i.e., the APPJ). As described in Section 3.3, the atmospheric-pressure air plasma jet (i.e., the soft plasma jet) can generate considerable amounts of $\mathrm{H}_{2} \mathrm{O}_{2}$ and $\mathrm{NO}_{x}$, but only a very small amount of $\mathrm{OH}$ radicals as compared to the APPJ. The concentrations of reactive oxygen and nitrogen species in the plasma-activated water produced by the soft plasma jet will be discussed in Section 3.3.
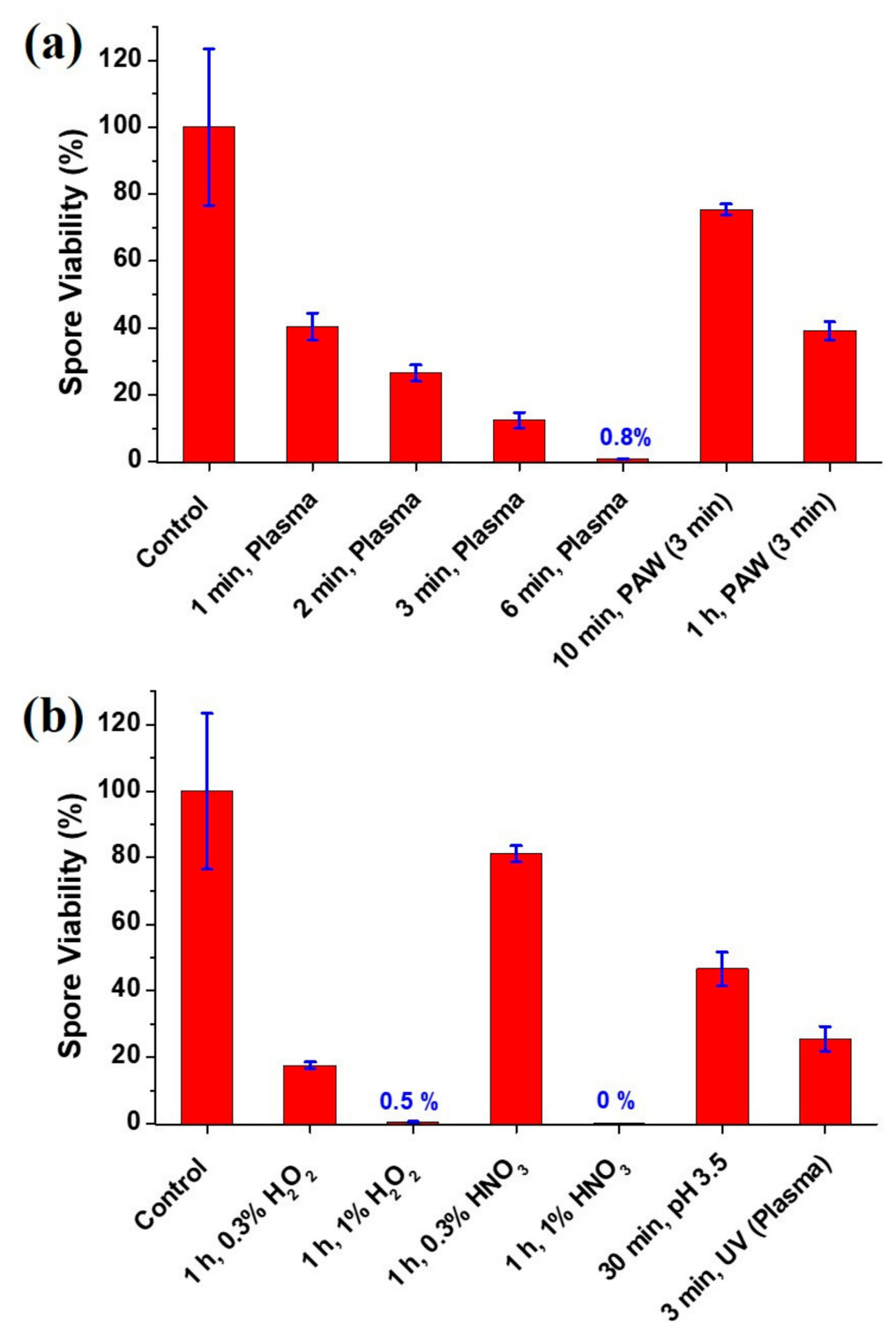

Figure 2. (a) Viability of the C. pruinosa spores treated by the atmospheric-pressure air plasma jet (soft plasma jet). The 1st, 2nd, 3rd, 4th, and 5th bars of Figure 2a represent the viability of the control, $1 \mathrm{~min}, 2 \mathrm{~min}, 3 \mathrm{~min}$, and $6 \mathrm{~min}$ plasma-treated C. pruinosa spores, respectively. (b) Viability of the C. pruinosa spores treated by $\mathrm{H}_{2} \mathrm{O}_{2}$ solutions, $\mathrm{HNO}_{3}$ solutions, acid water, and UV light. The 6th and 7 th bars of Figure $2 \mathrm{~b}$ represent the viability of $C$. pruinosa spores treated by acid water of $\mathrm{pH} 3.5$ and plasma-generated UV light, respectively.

To further study the long-lasting effect of plasma-induced reactive species on the spore viability, we treated C. pruinosa spores using the plasma-activated water. For this experiment, the plasma-activated water was prepared by treating sterile de-ionized water for 3 min with the soft plasma jet. The 
C. pruinosa spores were soaked in the plasma-activated water for $10 \mathrm{~min}$ and $1 \mathrm{~h}$, respectively. As shown in Figure 2a, the plasma-activated water significantly reduced the spore viability with an increase of soaking time. This result suggests that plasma-induced long-lived reactive species $\left(\mathrm{H}_{2} \mathrm{O}_{2}\right.$ and $\left.\mathrm{NO}_{x}\right)$ play an important role in fungal spore inactivation.

To confirm the role of $\mathrm{H}_{2} \mathrm{O}_{2}$ and $\mathrm{NO}_{x}$ in fungal spore inactivation, we examined the effect of $\mathrm{H}_{2} \mathrm{O}_{2}$ and $\mathrm{HNO}_{3}$ solutions on the viability of $\mathrm{C}$. pruinosa spores without plasma treatment. For this aim, C. pruinosa spores were treated for $1 \mathrm{~h}$ with $0.3 \%$ and $1 \% \mathrm{H}_{2} \mathrm{O}_{2}$ solutions, and for $1 \mathrm{~h}$ with $0.3 \%$ and $1 \% \mathrm{HNO}_{3}$ solutions. These treatments remarkably reduced the spore viability (Figure $2 \mathrm{~b}$ ). The spore viability was reduced by more than $99 \%$ with $1 \%$ solutions. These data suggest that $\mathrm{H}_{2} \mathrm{O}_{2}$ and $\mathrm{HNO}_{3}$ play an important role in the weakening of spore cell walls and cell death. Acid water and UV light also affected spore inactivation, but to a smaller degree than plasma treatment. These results indicate that not only $\mathrm{H}_{2} \mathrm{O}_{2}$ and $\mathrm{HNO}_{3}$ but also acid water and $\mathrm{UV}$ light can lead to irreversible intracellular damage in $\mathrm{C}$. pruinosa spores.

\subsection{Characteristics of the Soft Plasma Jet}

The soft plasma jet exhibited output characteristics of typical nonthermal atmospheric pressure plasma. Figure $1 \mathrm{~b}$ shows the typical voltage (peak voltage, $1.34 \mathrm{kV}$; rms voltage, $0.61 \mathrm{kV}$ ) and current (peak current, $2.76 \mathrm{~A} ; \mathrm{rms}$ current, $110 \mathrm{~mA}$ ) waveforms of the plasma discharge. The period of the applied voltage/current was $12 \mu \mathrm{s}$, and the duty ratio of the pulse-on and pulse-off times was $19 \%$. The soft plasma jet could transfer $3.3 \mathrm{~J} / \mathrm{s}$ to the sample. The optical emission spectrum of the soft plasma jet (Figure 1c) exhibited emission lines corresponding to $N_{2}$, atomic nitrogen, atomic oxygen, and the hydroxyl radical. Emission bands generated by radiative transitions of the second positive and first negative system of the excited molecular nitrogen were observed at 310 to $440 \mathrm{~nm}$. The emission lines at 777 and $822 \mathrm{~nm}$ can be attributed to atomic oxygen and atomic nitrogen, respectively [17-20]. The emission at $777 \mathrm{~nm}$ was produced by the oxygen atom transition $O\left(2 s^{2} 2 p^{3}\left({ }^{4} S^{0}\right) 3 s \rightarrow 2 s^{2} 2 p^{3}\left({ }^{4} S^{0}\right) 3 p\right)[18,19]$, and the emission at $822 \mathrm{~nm}$ was produced by the nitrogen atom transition $N\left(2 s^{2} 2 p^{3}\left({ }^{3} P\right) 3 s \rightarrow 2 s^{2} 2 p^{3}\left({ }^{3} P\right) 3 p\right)[18,20]$. These results are due to the experimental conditions of our plasma device operating at atmospheric pressure using air as the working gas. Because oxygen molecules received sufficient numbers of electrons from the plasma, they could be transformed into reactive oxygen intermediates through the following $\mathrm{O}_{2}$-reduction pathway: $\mathrm{O}_{2} \rightarrow \mathrm{O}_{2}^{-} \rightarrow \mathrm{H}_{2} \mathrm{O}_{2} \rightarrow \mathrm{OH} \rightarrow \mathrm{H}_{2} \mathrm{O}[21,22]$.

\subsection{Plasma-Activated Water and Plasma-Induced Intracellular ROS}

When the soft plasma jet was introduced into the aqueous solution, additional reactive species could be induced from the interaction between plasma radicals and water molecules [4,12]. Among the reactive oxygen species derived from the interaction of plasma radicals with the aqueous solution, $\mathrm{H}_{2} \mathrm{O}_{2}$ has the highest stability and the lowest reactivity [21]. $\mathrm{H}_{2} \mathrm{O}_{2}$ can induce the modification of cellular proteins [23]. Thus, $\mathrm{H}_{2} \mathrm{O}_{2}$ is an important factor deciding fungal spore inactivation. The concentrations of $\mathrm{H}_{2} \mathrm{O}_{2}$ in the plasma-activated water were measured using a QuantiChrom ${ }^{\mathrm{TM}}$ Peroxide Assay Kit (DIOX-250). By comparing the absorption spectrum of the 5-fold-diluted plasma-activated water with that of standard $30 \mu \mathrm{M} \mathrm{H} \mathrm{H}_{2} \mathrm{O}_{2}$, the concentration of $\mathrm{H}_{2} \mathrm{O}_{2}$ in the plasma-activated water treated for $3 \mathrm{~min}$ by the soft plasma jet was measured to be $137 \mu \mathrm{M}$, as shown in Figure 3a. The concentration of plasma-induced $\mathrm{H}_{2} \mathrm{O}_{2}$ increased with increasing plasma treatment time. Next, we investigated the $\mathrm{OH}$ radical concentration in the plasma-activated water treated by the soft plasma jet. Although the $\mathrm{OH}$ concentration of $0.2 \mu \mathrm{M}$ was found in the plasma-activated water treated for $3 \mathrm{~min}$ in the 48-well plate with a diameter of $11 \mathrm{~mm}$, it was too low in the plasma-activated water treated for $3 \mathrm{~min}$ in the 6-well plate with a diameter of $35 \mathrm{~mm}$. These results might be attributed to the fact that $\mathrm{OH}$ radicals are a short-lived reactive species with a lifetime of microseconds order in aqueous solution. Finally, plasma-induced reactive nitrogen species can also attack the spore cell wall and spore DNA [24]. The concentrations of $\mathrm{NO}_{x}\left(\mathrm{NO}_{2}^{-}\right.$and $\left.\mathrm{NO}_{3}^{-}\right)$in the plasma-activated water were measured 
using QuantiChrom ${ }^{\mathrm{TM}}$ Nitric Oxide Assay Kit (DIOX-100). By comparing the absorption spectrum of the 28-fold-diluted plasma-activated water with that of standard $100 \mu \mathrm{M} \mathrm{NO} O_{x}$, the concentration of $N O_{x}$ in the plasma-activated water treated for $3 \mathrm{~min}$ by the soft plasma jet was measured to be $3.14 \mathrm{mM}$, as shown in Figure 3b. The plasma-induced $\mathrm{NO}_{x}$ concentration increased with increasing plasma treatment time. The long-lived reactive species $\left(\mathrm{H}_{2} \mathrm{O}_{2}\right.$ and $\left.\mathrm{NO}_{x}\right)$ may contribute to the inactivation of C. pruinosa spores. Consequently, plasma-generated reactive species can affect the intracellular ROS of C. pruinosa spores.
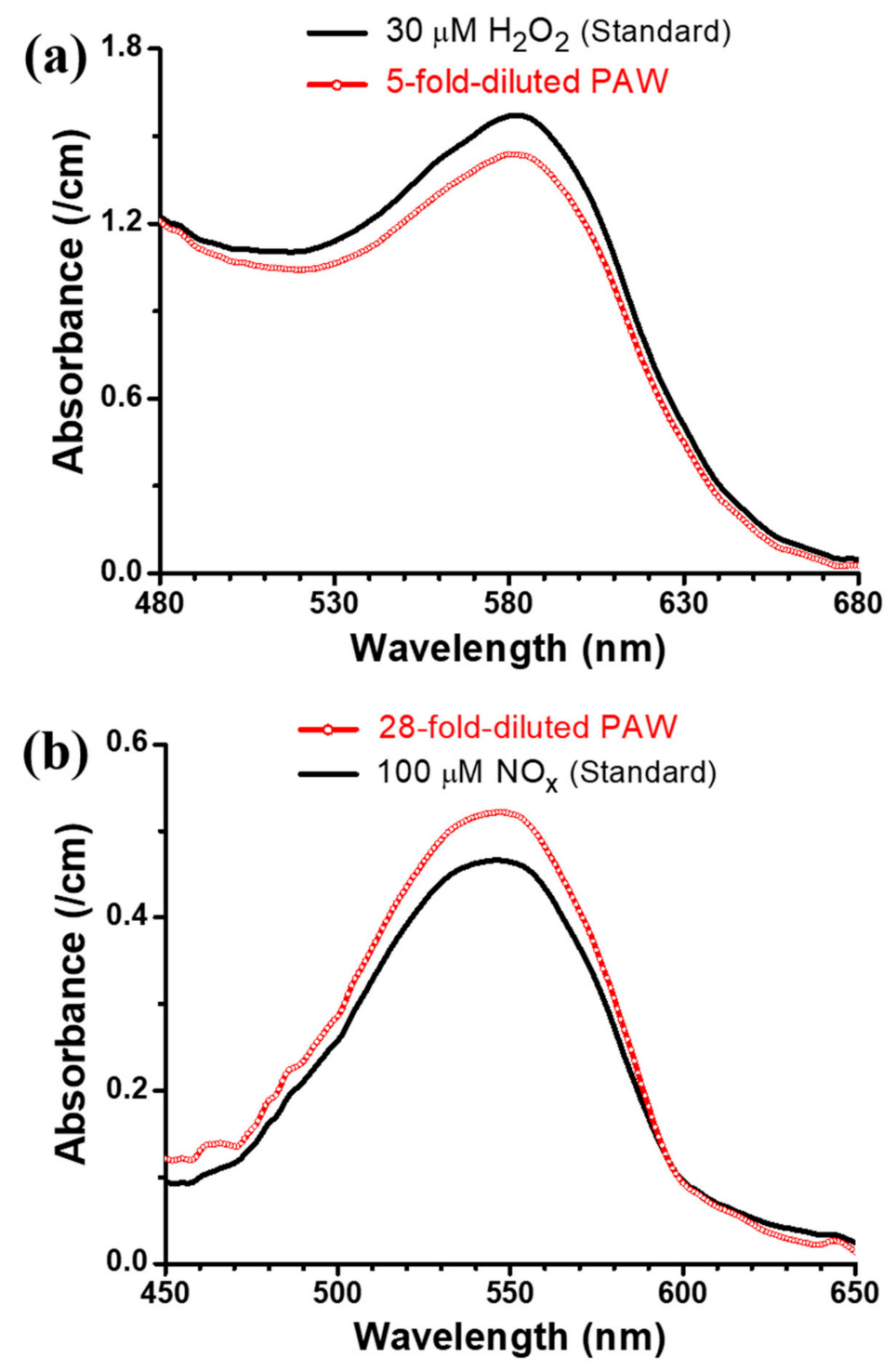

Figure 3. (a) Absorption spectra of 5-fold-diluted plasma-activated water and standard $30 \mu \mathrm{M}$ $\mathrm{H}_{2} \mathrm{O}_{2}$ solutions mixed with a QuantiChromTM Peroxide Assay Kit (DIOX-250). (b) Absorption spectra of 28-fold-diluted plasma-activated water and standard $100 \mu \mathrm{MNO} x$ solutions mixed with a QuantiChromTM Nitric Oxide Assay Kit (D2NO-100). The plasma-activated water was obtained by treating sterile de-ionized water for 3 min with the soft plasma jet.

To detect intracellular ROS generated inside the spore cell by the soft plasma jet, the fluorescence intensity of $\mathrm{H}_{2} D C F-D A$-stained C. pruinosa spores was measured using a flow cytometer. The black-colored curve in Figure 4 indicates that the control spores contained ROS at some level. This result indicates that the fungal cells could produce ROS internally. In fungi, intracellular ROS enhancement is accompanied by cessation of growth, involving not only changes of cellular morphology to adapt to 
the changed conditions, but also a decrease in intracellular oxidant concentration [25]. Fluorescence intensity increased with increasing plasma treatment time, indicating that the amount of intracellular ROS was clearly enhanced in the plasma-treated spores. The enhanced intracellular ROS in the fungal cell can, therefore, be attributed to the penetration of plasma-generated ROS into the cell, and/or ROS reactively forming via interactions between plasma-generated reactive species and the spore cell. The excess level of plasma-induced intracellular ROS may contribute to the inactivation of C. pruinosa spores.

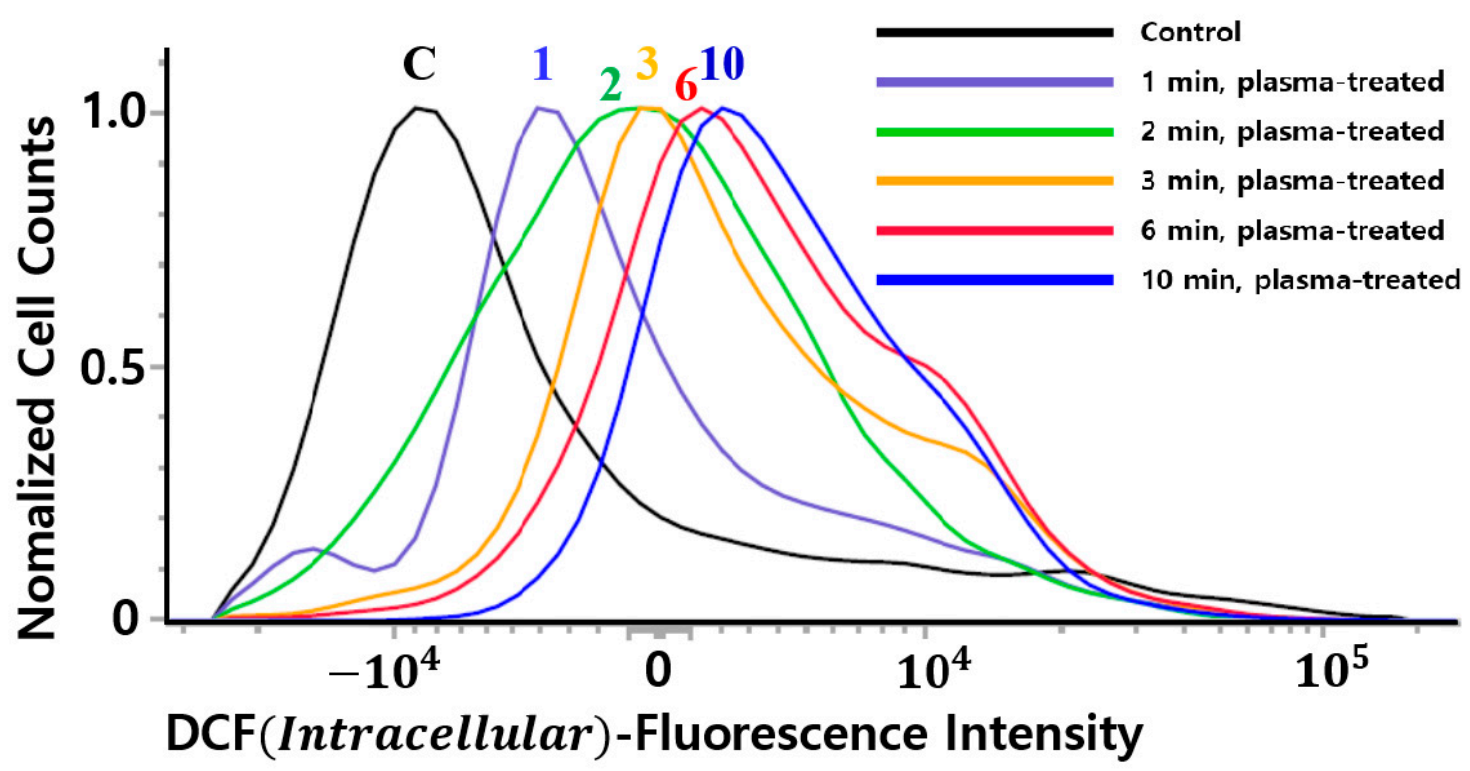

Figure 4. Fluorescence intensity of $\mathrm{H}_{2} D C F-D A$-stained $C$. pruinosa spores for intracellular reactive oxygen species generated by a soft plasma jet. C, 1, 2, 3, 6, and 10 represent intracellular ROS for the control, $1 \mathrm{~min}, 2 \mathrm{~min}, 3 \mathrm{~min}, 6 \mathrm{~min}$, and $10 \mathrm{~min}$ plasma-treated C. pruinosa spores, respectively.

\subsection{Morphology and Cell Wall Integrity of the Plasma-Treated C. pruinosa Spores}

The results described in Section 3.1 prompted an investigation into what kind of cellular damage from the soft plasma jet could lead to the death of the spores. Because the fungal spore surface is covered with a protective layer of the cell wall [26], we examined the possibility of cell wall damage. Figure 5 shows SEM images of the $C$. pruinosa spores before and after soft plasma jet treatments for $3 \mathrm{~min}$ and $10 \mathrm{~min}$. Cell morphology of the plasma-treated spores showed remarkable changes as compared with that of control spores. The plasma-treated spores were shrunken, ruptured, and flattened. The deformation can be explained by the fact that the intracellular space had been at least partially emptied of its contents and/or cell rigidity was diminished. These explanations imply that spore cell wall was deformed by the plasma treatment. Because cell membranes control traffic into and out of cellular components, damaged membranes could allow intracellular components, such as nucleic acids, proteins, and other metabolites, to possibly leak out and/or make the cell vulnerable to attack by soft plasma jet-triggered radicals and/or reactive species that could induce cell membrane pore-opening or breakage. 

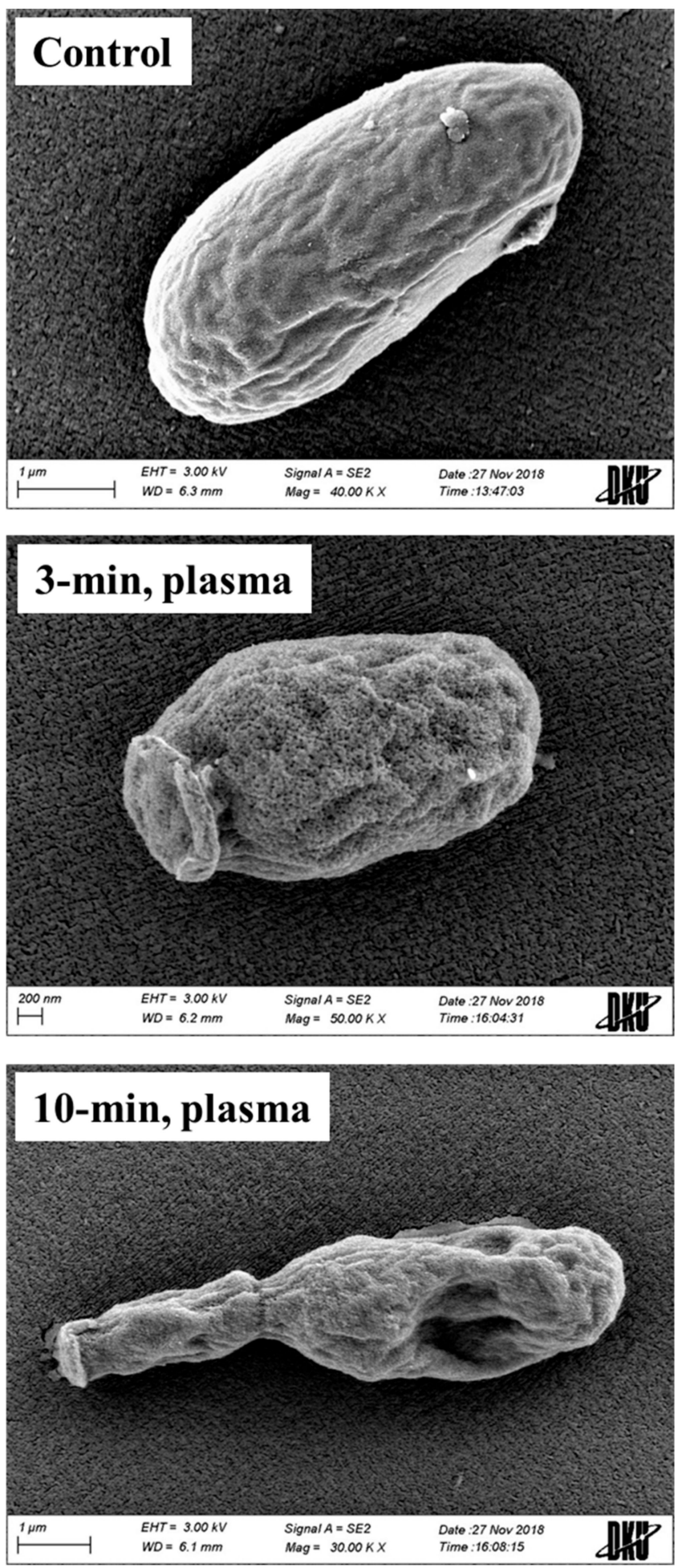

Figure 5. Typical SEM images of C. pruinosa spores treated by a soft plasma jet. C, 3, and 10 represent SEM images of the control, $3 \mathrm{~min}$, and $10 \mathrm{~min}$ plasma-treated spores, respectively.

To determine the level of structural damage in the membranes of spore cell walls, we stained plasma-treated and untreated spores with PI dye, which is impermeable through a normal membrane in living cells but permeable through the damaged membranes in dead cells. As shown in Figure 6, the fluorescence intensity of PI-stained C. pruinosa spores is clearly more intense in plasma-treated spores than in untreated spores, indicating that cell membranes are damaged and that cell wall integrity has decreased in the plasma-treated spores. 


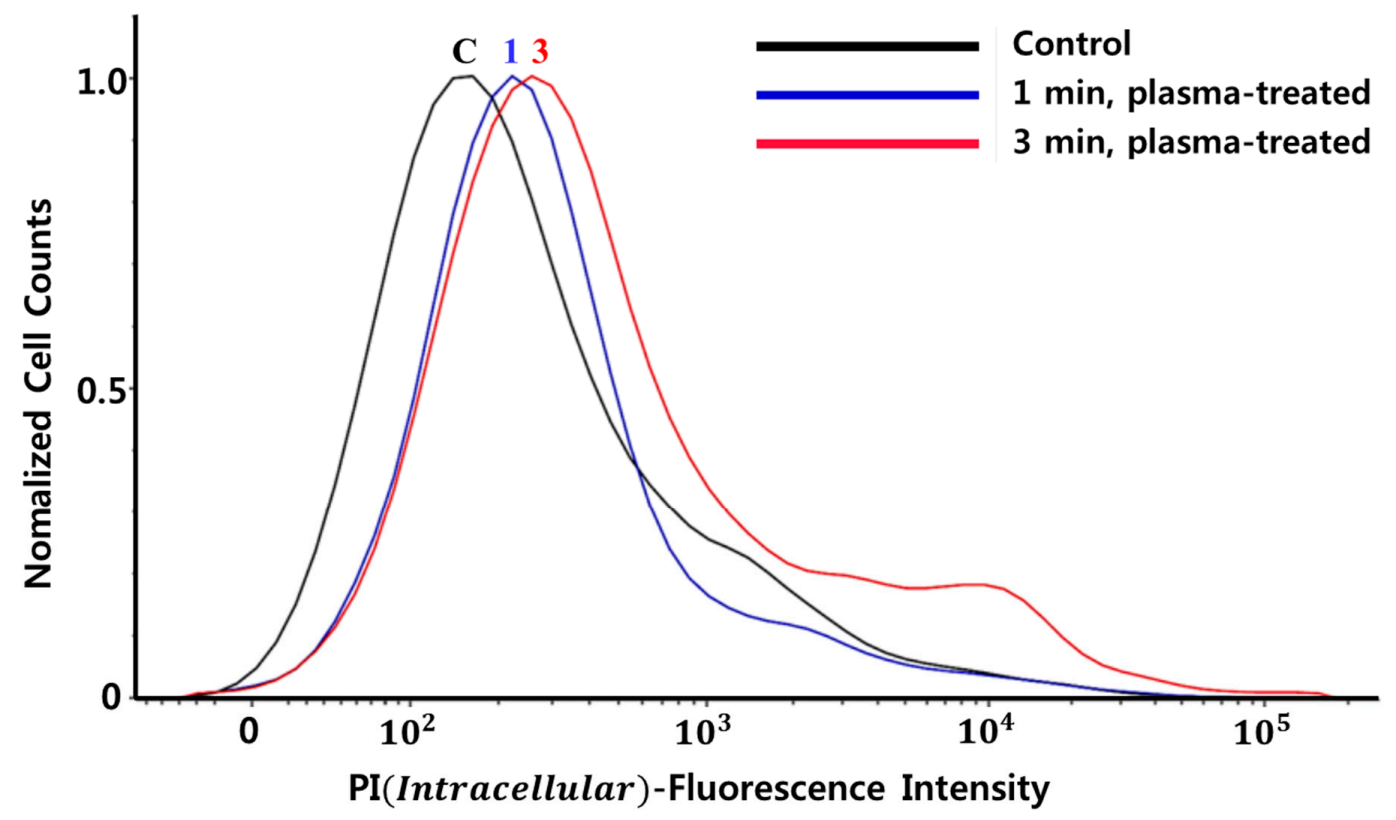

Figure 6. Fluorescence intensity of PI-stained C. pruinosa spores treated by the soft plasma jet. C, 1, and 3 represent the fluorescence intensity of PI-stained C. pruinosa spores for the control, $1 \mathrm{~min}$, and $3 \mathrm{~min}$ plasma-treated spores, respectively. Cell wall integrity was investigated by measuring the fluorescence intensity of C. pruinosa spores stained with a membrane-impermeable fluorophore, PI.

Figure 7 exhibits the $\mathrm{CD}$ spectra of the $C$. pruinosa spores treated by the soft plasma jet. The control CD spectrum of the plasma non-treated spores exhibited a negative dip at about $230 \mathrm{~nm}$ and $285 \mathrm{~nm}$. The CD dip at $230 \mathrm{~nm}$ might be attributed to the spore cell wall and/or membrane proteins [27], and the CD dip at $285 \mathrm{~nm}$ is attributed to ergosterol in the spore cell wall. The CD dip at $230 \mathrm{~nm}$ of the plasma-treated C. pruinosa spores was lower than that of the control. A decrease in the spore chirality was thought to be originated from the degradation of the spore cell wall and/or membrane proteins by the soft-plasma jet.

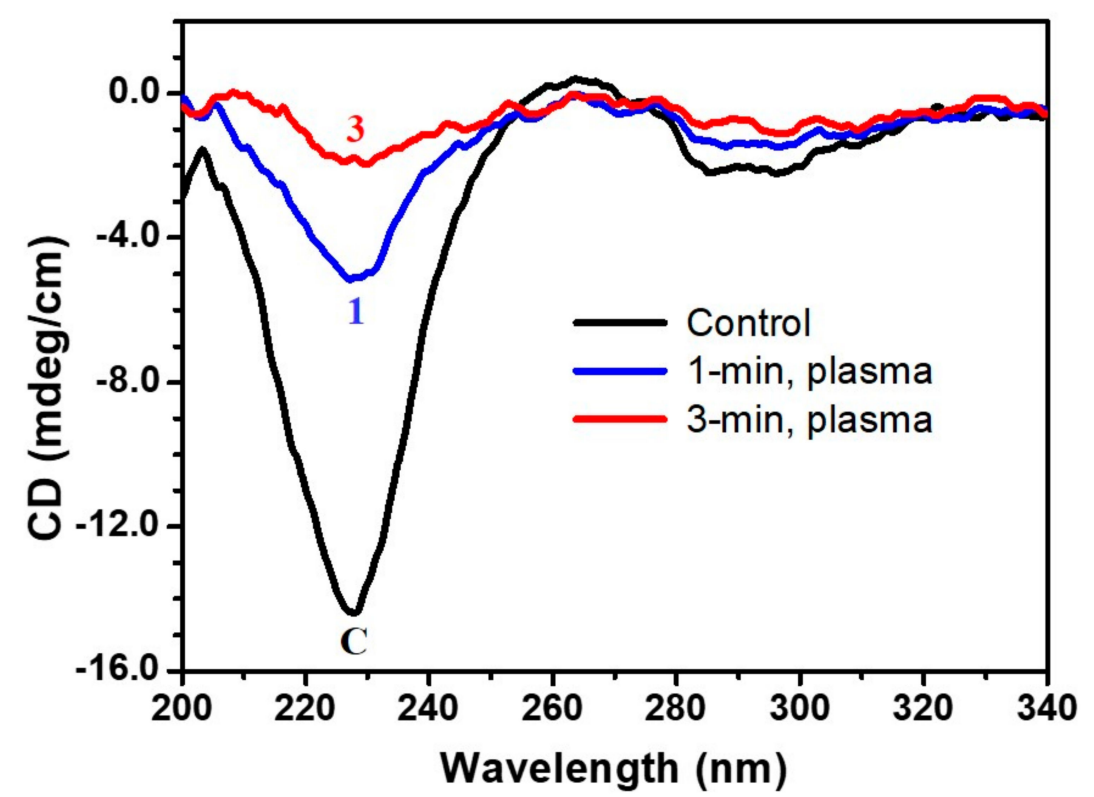

Figure 7. Circular dichroism spectra of the C. pruinosa spores treated by the soft plasma jet. C, 1 , and 3 represent $\mathrm{CD}$ spectra of the control, $1 \mathrm{~min}$, and $3 \mathrm{~min}$ plasma-treated C. pruinosa spores, respectively. 


\subsection{Flow Cytometric Analysis of DNA Damage in the Plasma-Treated C. pruinosa Spores}

Based on the spore viability results described in Section 3.1, DNA damage in plasma-treated C. pruinosa spores can be assumed. Figure 8 shows flow cytometric analysis of phosphorylated histone fluorescence of DNA damage caused by soft plasma jet treatment. When plasma-generated reactive species induce double-strand breakage in C. pruinosa DNA, it is always followed by phosphorylation of histones $[28,29]$. Therefore, measurement of phosphorylated histone $(\gamma-H 2 A X)$ can provide information on the degree of DNA damage. The level of histone fluorescence rose with plasma-treatment time, verifying that spore DNA damage was influenced by the duration of plasma treatment, and supporting the results shown in Figure 4: plasma-generated reactive species contribute to DNA damage of C. pruinosa spores.

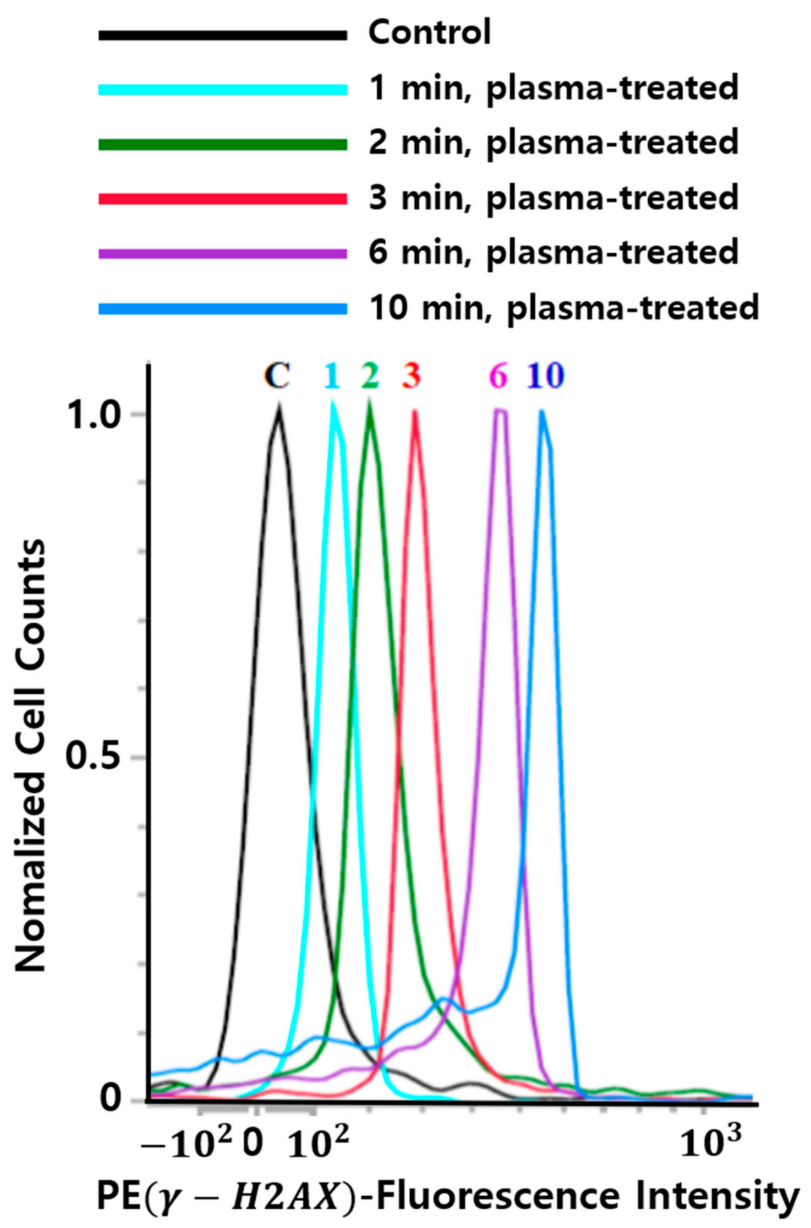

Figure 8. Flow cytometric analysis of phosphorylated histone fluorescence of C. pruinosa DNA damage caused by soft plasma jet treatment. C, 1, 2, 3, 6, and 10 represent phosphorylated histone fluorescence of the control, $1 \mathrm{~min}, 2 \mathrm{~min}, 3 \mathrm{~min}, 6 \mathrm{~min}$, and $10 \mathrm{~min}$ plasma-treated C. pruinosa spores, respectively.

\subsection{Electrophretic Analysis of DNA Damage in the Plasma-Treated C. pruinosa Spores}

In general, a single cell spore contains genomic DNA, which is a large molecule. Typically, DNA extraction results in a single high molecular DNA band during agarose gel electrophoresis. If genomic DNA is damaged due to physical shearing or chemical exposure, degradation occurs. DNA degradation can be visualized as a weakened high molecular DNA band and the smearing of DNA on agarose gels after staining with ethidium bromide or other dyes [30]. Smearing occurs when many bands originated from degradation go along the path of DNA movement in the gel. Considering this, we further analyzed DNA damage of C. pruinosa spores using agarose gel electrophoresis. DNA staining with Ecodye reveals that more DNA produces a stronger band intensity. Figure 9 shows the 
results of electrophoretically separated fungal spore DNA. A tight single strong DNA band with high molecular weight (a band of maker DNA lager than $13 \mathrm{~kb}$ ) and a very strongly smeared DNA trace lower than $500 \mathrm{bp}$ of the maker DNA (lane M) were present in lane 1 of the gel containing control DNA (from C. pruinosa spores without plasma treatment). This smeared trace of DNA degradation is common in genomic DNA extraction because this procedure involves disrupting cells, denaturation of nucleoprotein complex, inactivation of nucleases (which allows DNA samples to be exposed to heat or physical shearing), and residual nucleases remaining in the DNA samples [31]. Single high molecular DNA bands were also observed in lanes 2 and 3 of the gel containing DNAs from C. pruinosa spores with plasma treatment for 1 and $3 \mathrm{~min}$, respectively. However, the intensities of these single DNA bands in lanes 2 and 3 were weaker than that in lane 1 . Note that the single DNA band in lane 3 is visibly weaker than that in lane 2 . In addition, the smeared DNA in lanes 2 and 3 is less than $1 \mathrm{~kb}$ and is both less apparent than that in lane 1 . Smeared DNA less than $1 \mathrm{~kb}$ almost diminished in lanes 4 and 5. These results indicate that DNA degradation increased with increasing plasma treatment time. Furthermore, single high molecular DNA bands were not present in lanes 4 or 5, implying that plasma treatment for 6 or 10 min completely degraded the spore DNA. Overall, progressive degradation of DNA involving a reduced band intensity and the absence of a single high molecular band in the electrophretic pattern was observed with increasing plasma treatment time. These results showed that plasma-triggered DNA damage involved DNA degradation of C. pruinosa spores, which is detrimental to the biological activity of fungal spores.

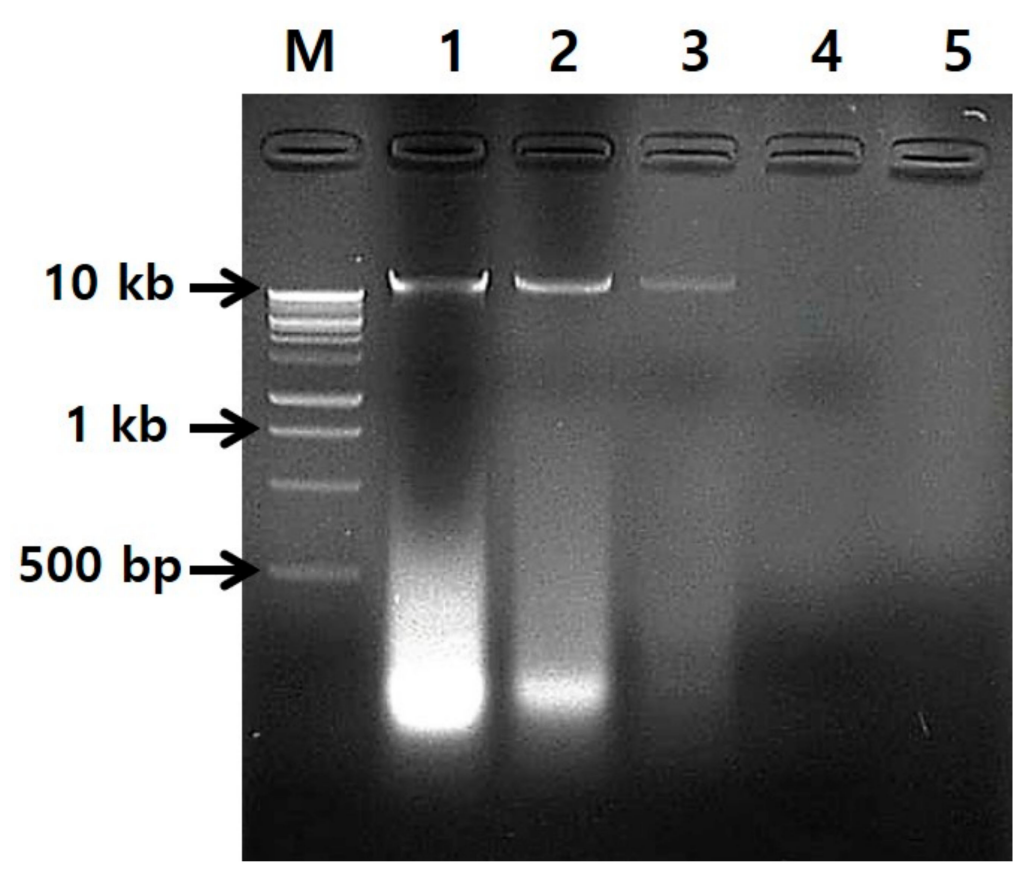

Figure 9. Electrophoretic analysis of DNA from C. pruinosa spores treated by a soft plasma jet. Lanes M and 1 represent $1 \mathrm{~kb}$ DNA marker and control DNA extracted from C. pruinosa spores without plasma treatment, respectively. Lanes 2, 3, 4, and 5 represent DNA extracted from $1 \mathrm{~min}, 3 \mathrm{~min}, 6 \mathrm{~min}$, and 10 min, plasma-treated C. pruinosa spores, respectively.

\section{Conclusions}

The spore viability and cell wall integrity of Cordyceps pruinosa were investigated to better understand the death mechanism of fungal spores by electric shock-free, atmospheric-pressure air plasma jet (i.e., the soft plasma jet). Plasma treatment significantly reduced the spore viability and damaged fungal DNA. This indicates that the viability of $C$. pruinosa spores can be controlled using a soft plasma jet that produces plasma radicals in the absence of electric shocks. As observed from the CD spectra, SEM images, and flow cytometric measurements, cell wall integrity was decreased 
by RONS from both the plasma itself and the plasma-activated water. Consequently, spore cell wall degradation provided a path by which RONS from the plasma could reach the intracellular components. Plasma-induced intracellular ROS are able to attack spore DNA and other intracellular components, as confirmed by electrophoresis analysis and phosphorylated histone measurement. In addition, the weakened spore cell walls resulted in a loss of intracellular components, eventually leading to cell death. Plasma radicals were analyzed using the optical emission spectrum of the soft plasma jet, and intracellular ROS were confirmed by measuring the fluorescence of $\mathrm{H}_{2} D C F-D A$-stained C. pruinosa spores. In this research, fungal spore inactivation was achieved by the soft plasma jet using air as the plasma working gas. This atmospheric-pressure air plasma jet (i.e., the soft plasma jet) generated considerable amounts of $\mathrm{H}_{2} \mathrm{O}_{2}$ and $\mathrm{NO}_{x}$ but a very small number of $\mathrm{OH}$ radicals as compared to the atmospheric-pressure $\mathrm{Ar}$ plasma jet (i.e., the APPJ); this indicates that plasma-induced long-lived reactive species $\left(\mathrm{H}_{2} \mathrm{O}_{2}\right.$ and $\left.\mathrm{NO}_{x}\right)$ play an important role in $\mathrm{C}$. pruinosa spore inactivation. In addition, an atmospheric-pressure air plasma jet allows for sterilization of fungal spores through the miniaturized plasma device. Thus, as demonstrated in this study, DNA damage and cell wall integrity loss by plasma-induced RONS were further clarified using a soft plasma jet.

The application of plasma treatment to fungal spores is versatile. Many fugal species that release large numbers of spores into the air are food and indoor air contaminants. Thus, a plasma apparatus with a sterilization function could be used for sanitary purposes in the food industry, medical manufacturing, and semi-conductors. Since an atmospheric-pressure air plasma jet can make it possible to sterilize fungal spores by miniaturized plasma, meticulous application of plasma-induced RONS may be possible. Regarding C. pruinosa, stress sources, such as light, could activate the production of spores and biological compounds. The red pigment of the fungus is known to have pharmacological activity of anti-oxidant, anti-inflammatory, and anti-allergic effects [32,33]. Thus, certain controlled levels of plasma radicals have potential as stress sources that trigger the production of spores and biological compounds. To control the level of plasma-induced RONS for such applications, it is necessary to understand the mechanism by which RONS affect $C$. pruinosa spore cells. Furthermore, to be used as potent biological control agents, information on spore survival under diverse stress conditions is important. Thus, the present work elucidated the effects of plasma-induced RONS as a stress source for C. pruinosa spores. In general, fungi utilize nonenzymatic antioxidants, such as reddish pigments, proline, trehalose, and polyols, to protect their cells from attacks by oxidative agents [25]. Currently, the roles of nonenzymatic antioxidants have not been thoroughly studied in C. pruinosa. To better understand the survival of $C$. pruinosa spores against plasma stress, further study of nonenzymatic antioxidant functions is required.

Author Contributions: S.H.K. and G.J.L. conceived and designed the experiments, analyzed the data, wrote the manuscript. H.N., J.E.K., J.Y.K., I.H., S.H.K., and J.L. performed the experiments and research. E.H.C. provided assistance in the plasma setup and the analysis of plasma-induced RONS. I.H. performed the flow cytometric analysis of plasma-treated spores.

Funding: This research was supported by the Basic Science Research Program through the National Research Foundation of Korea [Grant numbers NRF-2016M3A7B4909823 (Kim), NRF-2018R1D1A1B07040386 (Lee)], by the Korea Ministry of Environments as "The Environmental Health Action Program" (2016001360002), and in part by Kwangwoon University in 2019.

Conflicts of Interest: The authors declare no conflict of interest.

\section{References}

1. Fernandes, E.G.; Valerio, H.M.; Feltrin, T.; Van Der Sand, S.T. Variability in the production of extracellular enzymes by entomopathogenic fungi grown on different substrates. Braz. J. Microbiol. 2012, 43, 827-833. [CrossRef] [PubMed]

2. Strasser, H.; Vey, A.; Butt, T.M. Are there any risks in using entomopathogenic fungi for pest control, with particular reference to the bioactive metabolites of Metarhizium, Tolypocladium and Beauveria species? Biocontrol Sci. Technol. 2000, 10, 717-735. [CrossRef] 
3. Isaka, M.; Kittakoop, P.; Kirtikara, K.; Hywel-Jones, N.L.; Thebtaranonth, Y. Bioactive substances from insect pathogenic fungi. Acc. Chem. Res. 2005, 38, 813-823. [CrossRef] [PubMed]

4. Dobrynin, D.; Fridman, G.; Friedman, G.; Fridman, A. Physical and biological mechanisms of direct plasma interaction with living tissue. New J. Phys. 2009, 11, 115020. [CrossRef]

5. Li, Y.; Kang, M.H.; Uhm, H.S.; Lee, G.J.; Choi, E.H.; Han, I. Effects of atmospheric-pressure non-thermal bio-compatible plasma and plasma activated nitric oxide water on cervical cancer cells. Sci. Rep. 2017, 7, 45781. [CrossRef] [PubMed]

6. Iza, F.; Kim, G.J.; Lee, S.M.; Lee, J.K.; Walsh, J.L.; Zhang, Y.T.; Kong, M.G. Microplasmas: Sources, particle kinetics, and biomedical applications. Plasma Process. Polym. 2008, 5, 322-344. [CrossRef]

7. Lee, G.J.; Kwon, Y.W.; Kim, Y.H.; Choi, E.H. Raman spectroscopic study of plasma-treated salmon DNA. Appl. Phys. Lett. 2013, 102, 021911.

8. Lackmann, J.W.; Schneider, S.; Edengeiser, E.; Jarzina, F.; Brinckmann, S.; Steinborn, E.; Havenith, M.; Benedikt, J.; Bandow, J.E. Photons and particles emitted from cold atmospheric-pressure plasma inactivate bacteria and biomolecules independently and synergistically. J. Royal Soc. Interface 2013, 10, 20130591. [CrossRef]

9. Laroussi, M. Low temperature plasma-based sterilization: Overview and state-of-the-art. Plasma Process. Polym. 2005, 2, 391-400. [CrossRef]

10. Liu, F.; Sun, P.; Bai, N.; Tian, Y.; Zhou, H.; Wei, S.; Zhou, Y.; Zhang, J.; Zhu, W.; Becker, K.; et al. Inactivation of bacteria in an aqueous environment by a direct-current, cold-atmospheric-pressure air plasma microjet. Plasma Process. Polym. 2010, 7, 231-236. [CrossRef]

11. Sun, P.; Wu, H.; Bai, N.; Zhou, H.; Wang, R.; Feng, H.; Zhu, W.; Zhang, J.; Fang, J. Inactivation of Bacillus subtilis spores in water by a direct-current, cold atmospheric-pressure air plasma microjet. Plasma Process. Polym. 2012, 9, 157-164. [CrossRef]

12. Lee, G.J.; Sim, G.B.; Choi, E.H.; Kwon, Y.W.; Kim, J.Y.; Jang, S.; Kim, S.H. Optical and structural properties of plasma-treated Cordyceps bassiana spores as studied by circular dichroism, absorption, and fluorescence spectroscopy. J. Appl. Phys. 2015, 117, 023303. [CrossRef]

13. Kim, J.Y.; Lee, I.H.; Kim, D.; Kim, S.H.; Kwon, Y.W.; Han, G.H.; Cho, G.; Choi, E.H.; Lee, G.J. Effects of reactive oxygen species on the biological, structural, and optical properties of Cordyceps pruinosa spores. RSC Adv. 2016, 6, 30699-30709. [CrossRef]

14. Kanazawa, S.; Furuki, T.; Nakaji, T.; Akamine, S.; Ichiki, R. Measurement of OH radicals in aqueous solution produced by atmospheric-pressure LF plasma jet. Int. J. Plasma Environ. Sci. Technol. 2012, 6, 166-171.

15. Yun, Y.H.; Hyun, M.W.; Suh, D.Y.; Kim, Y.M.; Kim, S.H. Identification and characterization of Eurotium rubrum isolated from Meju in Korea. Mycobiology 2009, 37, 251-257. [CrossRef] [PubMed]

16. Aamir, S.; Sutar, S.; Singh, S.K.; Baghela, A. A rapid and efficient method of fungal genomic DNA extraction, suitable for PCR based molecular methods. Plant Pathol. Quar. 2015, 5, 74-81. [CrossRef]

17. Ershov, A.; Borysow, J. Dynamics of $\mathrm{OH}\left(X^{2} \Pi(v=0)\right.$ in high-energy atmospheric pressure electrical pulsed discharge. J. Phys. D Appl. Phys. 1995, 28, 68-74. [CrossRef]

18. Atomic Spectra Database in NIST Standard Reference Database 78 (ver 5.6). Available online: https: //physics.nist.gov/asd (accessed on 12 April 2019).

19. Sarani, A.; Nikiforov, A.Y.; Leys, C. Atmospheric pressure plasma jet in $\mathrm{Ar}$ and $\mathrm{Ar} / \mathrm{H}_{2} \mathrm{O}$ mixtures: Optical emission spectroscopy and temperature measurements. Phys. Plasma 2010, 17, 063504. [CrossRef]

20. Westblom, U.; Agrup, S.; Alden, M.; Cederbalk, P. Detection of nitrogen atoms in flames using two-photon laser-induced fluorescence and investigations of photochemical effects. Appl. Opt. 1991, 30, 2990-3002. [CrossRef]

21. Giorgio, M.; Trinei, M.; Migliaccio, E.; Pelicci, P.G. Hydrogen peroxide: A metabolic by-product or a common mediator of ageing signals? Nat. Rev. Mol. Cell Biol. 2007, 8, 722-728. [CrossRef]

22. Farr, S.B.; Kogoma, T. Oxidative stress responses in Escherichia coli and Salmonella typhimurium. Microbiol. Mol. Biol. Rev. 1991, 55, 561-585.

23. De Grey, A.D.N.J. $\mathrm{HO}_{2}$ : The forgotten radical. DNA Cell Biol. 2002, 21, 251-257. [CrossRef] [PubMed]

24. Burney, S.; Caulfield, J.L.; Niles, J.C.; Wishnok, J.S.; Tannenbaum, S.R. The chemistry of DNA damage from nitric oxide and peroxynitrite. Mutat. Res. Fundam. Mol. Mech. Mutagen. 1999, 424, 37-49. [CrossRef]

25. Gessler, N.N.; Averyanov, A.A.; Belozerskaya, T.A. Reactive oxygen species in regulation of fungal development. Biochemistry 2007, 72, 1091-1109. [CrossRef] [PubMed] 
26. Beauvais, A.; Latge, J.P. Special Issue: Fungal Cell Wall. J. Fungi 2018, 4, 91. [CrossRef] [PubMed]

27. Miles, A.J.; Wallace, B.A. Circular dichroism spectroscopy of membrane proteins. Chem. Soc. Rev. 2016, 45, 4859-4872. [CrossRef]

28. Tanaka, T.; Halicka, D.; Traganos, F.; Darzynkiewicz, Z. Cytometric Analysis of DNA damage: Phosphorylation of histone H2AX as a marker of DNA double-strand breaks (DSBs). Methods Mol. Biol. 2009, 523, 161-168.

29. Zhao, H.; Tanaka, T.; Halicka, H.D.; Traganos, F.; Zarebski, M.; Dobrucki, J.; Darzynkiewicz, Z. Cytometric assessment of DNA damage by exogenous and endogenous oxidants reports aging-related processes. Cytom. Part A 2007, 71, 905-914. [CrossRef]

30. Lee, P.Y.; Costumbrado, J.; Hsu, C.Y.; Kim, Y.H. Agarose gel electrophoresis for the separation of DNA fragments. J. Vis. Exp. 2012, 62, e3923. [CrossRef]

31. Doyle, K. The Source of Discovery: Protocols and Applications Guide; PROMEGA: Madison, WI, USA, 1996.

32. Kim, J.Y. Molecular Genetic Studies on the Insect-Borne Mushroom Fungus, Cordyceps Pruinosa Grown in Light and Dark Conditions. Ph.D. Thesis, Dankook University, Cheonan, Korea, 2016.

33. Lee, I.H. Study on the Phamacological Activities and Standard Compounds in Mycelial Extracts of Cordyceps Pruinosa. Ph.D. Thesis, Dankook University, Cheonan, Korea, 2016.

(C) 2019 by the authors. Licensee MDPI, Basel, Switzerland. This article is an open access article distributed under the terms and conditions of the Creative Commons Attribution (CC BY) license (http://creativecommons.org/licenses/by/4.0/). 